\title{
HIERARCHY OF VALUE PERCEIVED BY GROUPS OF USERS ABOUT THEIR NEIGHBOURHOOD
}

\author{
Michelle Nascimento da Silva ${ }^{1}$ and Luciana Inês Gomes Miron ${ }^{2}$
}

\begin{abstract}
The value perceived by the client is a concept that has attracted a growing interest among Lean Construction researchers. The perceived value, associated with the Means-End Chain Model and the laddering technique, has allowed for the understanding of the personal values influence on the users' perception of value. The application of this concept regarding the built environment on the neighbourhood, scale has the potential for contributing to the concept of value consolidation. The aim of this paper is to identify and compare the perception of value of two user groups of a neighbourhood. The research strategy adopted was case study. The main study contributions refer to the contribution of the perception of value knowledge in the complex relationship between users and the built environment.
\end{abstract}

Keywords: perceived value, personal values, means-end chain, laddering, neighbourhood.

\section{INTRODUCTION}

The application of the perceived value concept has attracted the interest of a number of Lean Construction researchers (Santos et al. 2004; Lima et al. 2009; Miron and Formoso 2010; Bonatto et al. 2011; Brito and Formoso 2014; Peltokorpi et al. 2016) due to its potential for contributing to the consolidation of the concept of value. Woodruff and Gardial (1996) state that the value perceived by the client is "the consumer perception on what they want to happen in a specific situation of use, with the help of a product or a service offer, in the sense of reaching a proposal or goal."

In a wider context, built environment researchers have identified the value perceived by their clients as a relevant concept, backed up by extensive research related to definition, understanding and the attempt at measuring the perception of value by the clients and users (Coolen and Hoekstra 2001; Coolen 2006; Miron and Formoso 2010; Zinas and Jusan 2010; Bonatto et al. 2011; Kowaltowski and Granja 2011; Zinas 2013; Brito and Formoso 2014; Hentschke et al. 2014). Most of these investigations have adopted approaches of the marketing field as a reference. In these investigations, the perceived value has been associated with the concept of personal values, which results from social psychology (Rokeach 1973).

Despite the potential of this approach for value perception analysis of users and clients, there is still a lack of research focusing on the built environment on the neighbourhood scale. Most of the existing studies on the built environment has focused on the scale of buildings. The neighborhood scale has a greater complexity because of the number of different typologies of buildings, infrastructure and large number of users (residents,

PhD Student, Programa de pós-graduação em Planejamento Urbano e Regional (PROPUR) Federal University of Rio Grande do Sul, Brazil, michelly_nds@yahoo.com.br

$2 \mathrm{PhD}$, Associate Professor, School of Architecture, Department of Architecture, Federal University of Rio Grande do Sul, Brazil, luciana.miron@ufrgs.br 
traders and frequenters. Besides this, the personal values dimension (Rokeach 1973; 1981) has not been properly explored in the investigations related to the built environment.

The built environment 'neighbourhood' can be understood by its plurality of usages, users, and stakeholders, as well as by the coexistent negotiations and conflicts resulting from this overlapping of interests. Thus, the neighborhood has been presenting itself as a problem of use management of great complexity. Considering this, the investigations on the perception of value in neighbourhoods has the potential for contributing to the knowledge of value generation in the complex relationship between users and the built environment.

This paper reports part of a master's degree research in which one of the research questions was: what are the relationships between personal values and the perception of value of user groups (residents and traders) of a neighbourhood? Because of the absence of identified knowledge, taking the Means-end Chain Model as a theoretical base, this paper aims at identifying and comparing the perception value of two user groups of a neighbourhood. Identification is understood as the deployment of the relations between the personal values and the perception of value by the user groups.

\section{Perception Of Value and Personal Values}

\subsection{Means-End Chains and the Hierarchy of Perceived Value for the User}

The examples of the marketing field research that contribute to the understanding of the perceived value by the clients and users are the Means-End Chain Models (Gutman 1982; Reynolds and Gutman 1988) and the hierarchy of perceived value (Woodruff and Gardial 1996; Woodruff 1997). Strongly based on the Means-end Chain Model proposed by Gutman (1982), Wooddruff and Gardial (1996) organized the hierarchy of value model, which proposes that the clients' perception can be presented through a value hierarchical model with three levels of interconnected abstraction: the product attributes, the consequences of the use of a particular product and its user's personal values.

According to Gutman, a widely applied method to build Means-End Chains is the laddering technique. In this technique, beginning with in-depth interviews, clients (consumers, users) translate the products' attributes into their resulting consequences, and the consequences are, in turn, translated into personal values orientation (Gutman 1982). Through the laddering technique, it is possible to identify the client's (user's) web of meaning. The constructs are directly connected and form a hierarchy: attributes, consequences and values $(\mathrm{A}-\mathrm{C}-\mathrm{V})$. This hierarchy can be represented by ladders, which facilitate the understanding of the connection between the more concrete levels (attributes) to the more abstract ones (consequences and values). The ladders assist in the subject's (user's) mapping of the hierarchy of value (HVM).

\subsection{Personal Values}

The concept of personal values was presented in investigations of the sociology field (Thomas and Znaniecki 2004), and also those of anthropology (Kluckhohn 1968). In the domain of social psychology, Rokeach (1973) and Schwartz (1992) are the most cited authors in the organization of theories on personal values. The studies coming from these different knowledge areas have affected marketing research on the perception of value. In this regard, Woodruff (1997) states that the client's (user's) perception of value is associated with personal values. Woodruff (1997) defines the personal values as being lasting, relatively stable, intrinsic beliefs that consist of mental representations of need, 
and which are used by subjects as a base for equating decision and conflict processes. Moreover, these 'needs' help to explain why consumers make decisions (purchase and consumption) differently (Woodruff 1997).

Rokeach (1973) distinguishes personal values into instrumental (means) and terminal (ends) values. According to the author, this difference between personal values makes it possible to consider the existence of a functional relationship between the terminal and instrumental values. For Rokeach (1981), the terminal values are the favourite final states of existence; on the other hand, the instrumental values are the favourite social conduct and behaviour modes to achieve personal goals. The difference between personal values is relevant because it is employed in the stratification of the hierarchy of value. In the marketing field, personal values have been studied because they affect the perception of value in product use and purchase. In the built environment, personal values could help to understand the client's perceived value, as well as the attributes that can generate value in a project. In the environment built on a neighbourhood scale, the influences of personal values on the users' perception of value can help in the negotiation of conflicts related to neighbourhood management.

\section{RESEARCH METHOD}

The research strategy adopted was case study because a contemporary phenomenon within its real-life context was investigated; where the boundaries between phenomenon and context are not clearly evident; and in which multiple sources of evidence were used (Yin 1994). The research was made in the Cidade Baixa neighbourhood in the city of Porto Alegre, southern Brazil. In this neighbourhood, the Town Hall formed a Work Group (WG) with the aim of equating the conflicts of interest between two user groups: residents and traders. Nightlife noise was the main conflict negotiated between the user groups. The WG, through a municipal decree, readjusted the working hours of the night trading places (bars, restaurants, coffeehouses, and diners). The nocturnal activities (gastronomy and entertainment) are important and profitable for traders, but they generate noise and disturb the rest time of the residents. The selection of these two user groups was based on the engagement of both in the negotiation of the conflict regarding neighbourhood management. All users involved in the negotiations were part of associations (residents or traders).

Table 1: User Groups, Population and Sample Collected.

\begin{tabular}{c|c|c|c}
\hline User Groups & Number and Type & Population (N) & Collected Sample (n) \\
\hline Residents & 90 residential units & 90 & 7 \\
Traders & 67 trade facilities & 67 & 6 \\
\hline
\end{tabular}

To define the sample collected, the population, the response saturation and the time required for the research development were considered. The population was considered as: the number of all engaged residents (members of residents' associations) and the number of all engaged traders (members of traders' associations). The respondent selection was made based on a simple random sample. Saturation was considered according to Coolen and Hoekstra (2001): "when the interviews do not produce any new information one stops 
the interviewing because the exploration process is saturated". Table 1 presents the user groups, population, and sample collected.

The perception of value of both groups was presented through the application of the laddering technique and HVM. The laddering technique was applied in two crucial steps: 1) data collection and b) analysis and interpretation results.

The data collection was made between October and November 2013. A semi-structured in-depth interviewing script was organized in which the following constructs were addressed: Coexistence, Accessibility, Image, Environmental Comfort and Safety (previously identified in the exploratory phase of the research). Interview script pilot trials had been made in the Cidade Baixa neighbourhood with representatives from both engaged user groups (which are not part of the final collected sample).

\subsection{Results Analyses and Interpretation}

To perform the generated results analysis through the laddering technique, four steps were followed: a) Content Analysis; b) Generating the Implication Matrix; c) Constructing the Hierarchical Value Map - HVM; and d) Determining Dominant Perceptual Pathways (cutoff).

Table 2: Example of summary-codes generated in the research.

\begin{tabular}{|c|c|}
\hline \multicolumn{2}{|r|}{ A-C-V Sequence } \\
\hline $\begin{array}{l}\text { Terminal } \\
\text { Values }\end{array}$ & $\begin{array}{l}\text { HAPPINESS - well-being, feeling well, personal satisfaction, better life, } \\
\text { living well, optimizing life. }\end{array}$ \\
\hline $\begin{array}{l}\text { Instrumental } \\
\text { Values }\end{array}$ & ORGANIZATION - neat, clean. \\
\hline $\begin{array}{l}\text { Psychosocial } \\
\text { Consequences }\end{array}$ & $\begin{array}{l}\text { TRANQUILITY - silence, rest, relaxation, ease, quiet, concentration, } \\
\text { privacy, sleeping }\end{array}$ \\
\hline $\begin{array}{c}\text { Functional } \\
\text { Consequences }\end{array}$ & $\begin{array}{l}\text { ENVIRONMENTAL COMFORT - appropriate furniture, appropriate } \\
\text { environment for specific use, clean, dimensions, security, thermal comfort. }\end{array}$ \\
\hline $\begin{array}{l}\text { Abstract } \\
\text { Attributes }\end{array}$ & $\begin{array}{l}\text { MAINTENANCE - well maintained, preserved, clean, quality of the place, } \\
\text { well preserved, good pavement. }\end{array}$ \\
\hline $\begin{array}{l}\text { Concrete } \\
\text { Attributes }\end{array}$ & $\begin{array}{l}\text { INFRASTRUCTURE - transport, lighting, urban cleaning, rubbish } \\
\text { collection, green areas, trees, parks, vegetation, pavements/streets and } \\
\text { roads, large pavements, bikeways, traffic lights, parking areas, underground } \\
\text { parking, traffic signs, entry sign, sanitation. }\end{array}$ \\
\hline
\end{tabular}

Considering the contributions of Zinas and Jusan (2010), the categorizations of each element were sub-divided into: (F) Abstract or Concrete Attribute; (C) Psychosocial or Functional Consequence; (V) Terminal or Instrumental Value, thereby creating a chain (sequence A-C-V). Based upon this, the summary table was created with the codes of the elements. For example: for Concrete Attributes, one possible code is "INFRASTRUCTURE", which represents a range of words mentioned by the interviewees. Ultimately, starting with the attributes, the interconnected elements were identified, driven by the A-C-V sequence. The ladders were formulated to represent in summary the respondent's way of thinking. Table 2 presents an example of the summary-codes generated in the research. 
All data were inserted and processed in the LadderUX ${ }^{3}$ tool. This resource was only applied in the results analysis and interpretation results step. The A-C-V sequence elements were decoded and separated, thereby generating the ladders. The subjects' ladders were inserted in an implication matrix, showing all existing relations between the items. Subsequently, predominant associations between the said items were graphically represented in the HVM.

\section{RESUlTS AND DisCUSSION}

The HVM and laddering technique allow for the clarification of a wide range of connections between the main attributes of the neighbourhood and the main personal values. Substantial input was required regarding theoretical basis, constructs definition, and the main neighbourhood attributes identification, as perceived by both user groups.

The laddering technique demanded specific attention regarding the definitions of each summary-code and construct used in this work. More in-depth research was required for the summary-codes definition in the base theory of environment-behaviour, for example, infrastructure, mix of uses, maintenance, accessibility, image, environmental comfort, sense of security; social science, for example, counter-uses, bohemian neighbourhood, sociability and coexistence; social psychology, for example. instrumental and terminal values; and marketing, for example, perception of value and means-end chains $\mathrm{A}-\mathrm{C}-\mathrm{V}$ ) areas. Table 3 shows the main results obtained through the laddering technique in the research.

Table 3: Main results obtained through the application of the laddering technique.

Hierarchical Value Map (HVM): more frequently mentioned elements that have a more evident relation than other items from the $\mathrm{A}-\mathrm{C}-\mathrm{V}$ chain.

\begin{tabular}{|c|c|}
\hline Residents & $\begin{array}{l}\text { —“infrastructure - maintenance - environmental comfort - tranquility- happiness" } \\
\text { _" infrastructure - maintenance - sense of security - happiness" } \\
\text { _"mix of uses - users diversity - sociability - coexistence - respect - happiness" } \\
\text { _"night entertainment - bohemian neighbourhood - sociability - coexistence - } \\
\text { respect - happiness" } \\
\text {-“infrastructure - maintenance - image - good impression” }\end{array}$ \\
\hline Traders & $\begin{array}{l}\text {-“infrastructure - maintenance - image - successful - prosperity" } \\
\text { _"infrastructure - maintenance - image - successful - accomplishment" } \\
\text { _" infrastructure - accessibility/centrality - successful - prosperity” } \\
\text {-"policing/surveillance- availability - sense of security - safety" } \\
\text {-"night entertainment - bohemian neighbourhood - appeal - coexistence - respect” }\end{array}$ \\
\hline
\end{tabular}

Through the laddering, the relations between personal values and perceptions were more clearly displayed in the Implication Matrix and the Hierarchical Value Map, as exemplified in Figures 1 and 2.

\footnotetext{
${ }^{3}$ http://ladderux.org/
} 


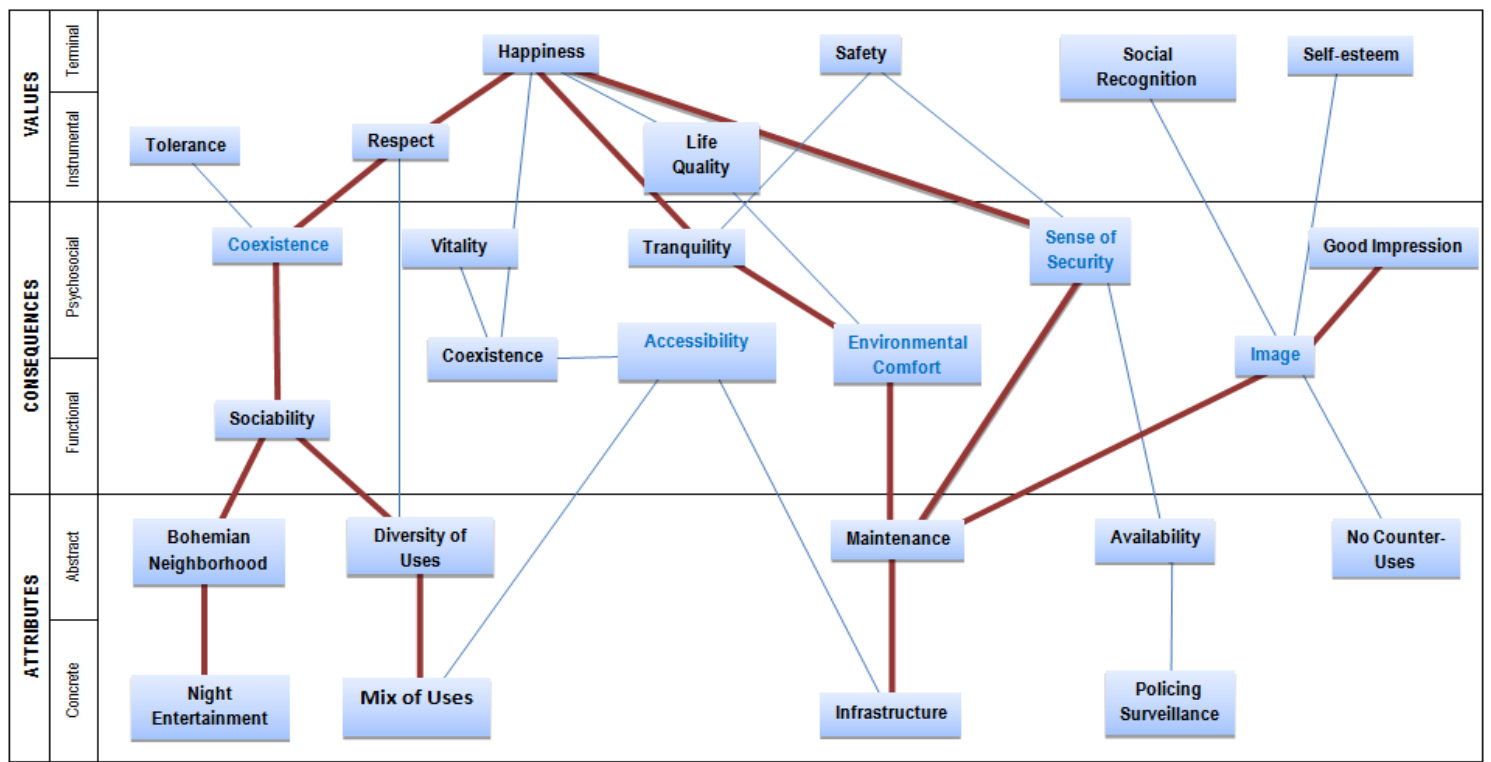

Figure 1: Residents HVM.

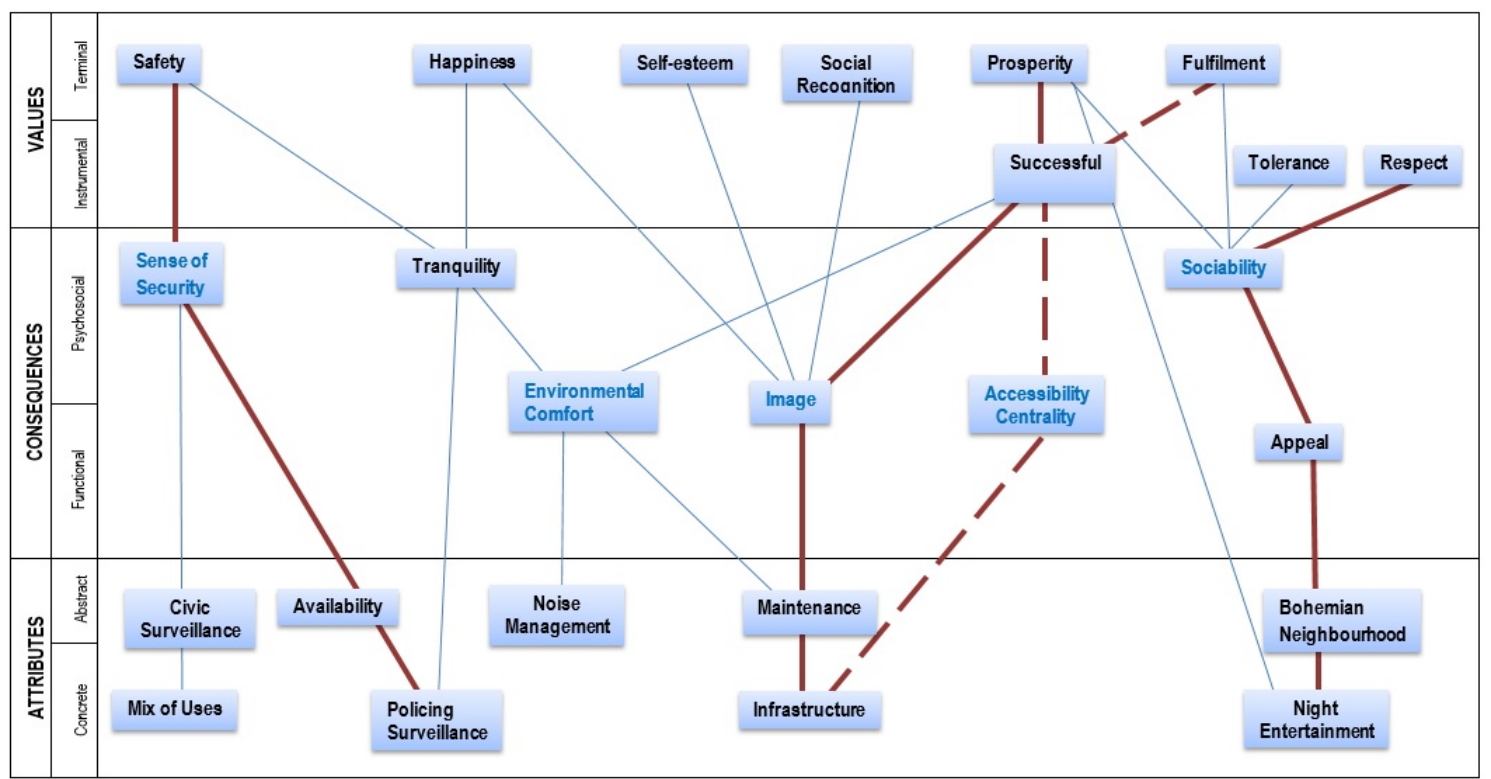

Figure 2: Traders HVM.

Regarding the concrete attribute 'night entertainment', both groups consider that this attribute makes the neighbourhood bohemian (abstract attribute). Sociability (psychosocial consequence) benefits from the neighbourhood's appeal due to its many nightlife-driven establishments. Whereas residents link these attributes to the terminal value, happiness, traders connect them to the terminal values of prosperity and accomplishment.

The infrastructure (concrete attribute) and maintenance (abstract attribute) were considered by both user groups as a crucial attribute to a positive assessment of the aspects of the neighbourhood. Maintenance of the public spaces assists in a given space being appointed prestige and appropriation. The prestige aspect can be observed in the research results in both groups from the personal values that arise due to maintenance, such as social recognition and self-esteem. 
It can therefore be concluded that the laddering technique has made it possible to identify that the maintenance of public equipment and service infrastructure (transport, lighting, urban cleaning, rubbish collection, green areas, trees, parks, vegetation, pavements/streets and roads, large pavements, bikeways, car parking, traffic lights, traffic signs, entry signs and sanitation) creates positive perceptions because it makes it possible to reach the consequences of use as a good image. Maintenance of public spaces helps a given space to be surrounded by prestige and appropriation. The extent of this consequence seeks to attain different final states of existence (terminal values) for both studied user groups. For the residents, a good image is more related to social recognition and self-esteem values, and prosperity and accomplishment for the traders.

\section{CONCLUSIONS}

The detailed analysis in the perception of value of the different user groups, using the theoretical basis Means-End Chain, the laddering technique application and HVM, has assisted in improving the concept of attributes and consequences in the value hierarchical perception in the built environment on the neighbourhood scale. The HVMs as a visual display shows more clearly the relationships between personal values and the perception of value regarding the neighbourhood for each user group. Thus, they have facilitated the perception comparison between both user groups, making the variations clear between the hierarchical values.

The influence of personal values on users' perception of value can lead to an important contribution to the perceived value concept because it has allowed for a wider understanding of the value generation to be used in the built environment. Personal values are implicit motivational goals (Schwartz 1992) that have not been analysed by the lean construction community. As shown in the case study, different personal values result in similarities and differences in users' perceived value. Therefore, the methods and constructs identified here could be applied for research and practices of the IGLC community as a whole.

Considering the multi-disciplinary aspect related to the research regarding the built environment and the user's interaction with this environment, the use of techniques from different knowledge areas is important. Such studies could aid in the negotiation process of conflicts between different client groups and stakeholders of the built environment. Besides this, given the complexity of neighbourhood use management, such studies present a potential for contributing to the development management of complex projects.

\section{REFERENCES}

Bonatto, F.S., Miron, L.I. and Formoso, C.T. (2011). 'Evaluation of Social Housing Projects Based on User Perceived Value Hierarchy' In: 19th Annual Conference of the International Group for Lean Construction. Lima, Peru, 13-15 jul.

Brito, J.N.D.S. and Formoso, C.T. (2014). 'Using the Means-End Approach to Understand Perceived Value by Users of Social Housing Projects' In: 22nd Annual Conference of the International Group for Lean Construction. Oslo, Norway, 25-27 Jun 2014.

Coolen, H. and Hoekstra, J. (2001). Values as Determinants of Preferences for Housing Attributes. Journal of Housing and Built Environment. v. 16, n. 3/4, p. 285-306.

Coolen, H. (2006). The meaning of dwellings: An ecological perspective. Housing, Theory and Society, v. 23, n. 4, p.185-201. 
Gutman, J. (1982). A means-end chain model based on consumer categorizations processes. Journal of Marketing. V. 48: 60-72, spring.

Kluckhohn, C.K.M. (1968). Values and value orientation in the theory of action. In: PARSONS, T.; SHLDS, E. (eds). Toward a general theory of action. Cambridge, MA, Harvard University Press.

Kowaltowski, D. C. C. K. and Granja, A. D. (2011). The concept of desired value as a stimulus for change in social housing in Brazil. Habitat International, v. 35, n. 3, p. 435446, jul.

Lima, L.P., Miron, L.I., Leite, F. and Formoso, C.T. (2009). 'Perceived Value in Social Housing Projects' In: 17th Annual Conference of the International Group for Lean Construction. Taipei, Taiwan, 15-17 Jul 2009.

Miron, L.I. and Formoso, C.T. (2010). 'Value Generation in Social Housing Projects: A Case Study on the City Entrance Integrated Program in Porto Alegre, Brazil' In 18th Annual Conference of the International Group for Lean Construction. Haifa, Israel, 14-16 Jul 2010.

Peltokorpi, A., Seppänen, O. and Noorizadeh, A. (2016). 'Project Lifecycle Approach to the Perceived Value of Suppliers: A Study of a Finnish Contractor' In:, 24th Annual Conference of the International Group for Lean Construction. Boston, USA, 20-22 Jul.

Reynolds, T. J. and Gutman, J. (1988). Laddering theory, method, analysis, and interpretation. Journal of Advertising Research.

Rokeach, M. (1973). Beliefs, attitudes and values. New York: The Free Press.

Rokeach, M. (1981). Understanding Human Values: individual and societal. New York: The Free Press.

Santos, A.D., Kristmann, V.B. and Fischer, S. (2004). 'Assessing Total Value Requirements on Low Income Houses in Brazil' In: 12th Annual Conference of the International Group for Lean Construction. Helsingør, Denmark, 3-5 Aug.

Schwartz, S. H. (1992). Universals in the content and structure of values: Theory and empirical tests in 20 countries. In M. Zanna (Ed.), Advances in experimental social psychology (Vol. 25, pp. 1-65). New York: Academic Press.

Thomas, W. I. and Znaniecki, F. (2004). El campesino polaco en Europa y en América. Madrid: CIS.

Woodruff, R. B. (1997). Customer Value: the next source for competitive advantage. Journal of the Academy of Marketing Science, v. 25, n. 2: 139-153.

Woodruff, R. B. and Gardial, S. (1996). Know Your Customer: new approaches to understanding customer value and satisfaction. S.l.]: Blackwell Publishing.

Yin, Robert K. Case Study Research: design and methods. 2. Ed. California: Sage Publications, 1994.

Zinas, B. Z. and Jusan M. M. (2010). Theoretical Framework of Means-End Chain Model for Measuring Housing Environment Choice and Preference. 4th International Conference on Built Environment in Developing Countries, USM Penang-Malaysia, 1st- 2nd December.

Zinas, B. Z. (2013). Laddering as a Research Technique for Measuring Housing Choice and Preference. Journal of Environmental Sciences and Resources Management, v. 5, n. 2. 